\title{
Pengembangan model pembelajaran tematik integratif penjasorkes berbasis permainan siswa sekolah dasar
}

\author{
Agung Widodo \\ Universitas Muhammadiyah Sukabumi \\ agung.sport5@gmail.com
}

\begin{abstract}
Abstrak
Penelitian ini bertujuan untuk menghasilkan model pembelajaran tematik integratif Penjasorkes berbasis permainan bagi siswa sekolah dasar kelas 1 Kecamatan Gantiwarno Klaten. Penelitian ini merupakan penelitian dan pengembangan yang terdiri atas dua tahapan yaitu tahap penelitian pendahuluan terdiri dari kajian literatur, kajian penelitian relevan, studi lapangan dan tahap pengembangan terdiri perencanaan, validasi ahli, uji skala kecil, dan uji skala besar. Validasi melibatkan 3 orang ahli. Uji skala kecil dilakukan terhadap 16 siswa kelas 1 dan 2 orang guru di sekolah dasar Muhammadiyah Gantiwarno. Uji skala besar dilakukan terhadap dua kelas yang masing-masing terdiri dari 26 siswa kelas 1 dan 3 orang guru di sekolah dasar Muhammadiyah Gantiwarno dan sekolah dasar Negeri Ngandong 2. Hasil penelitian berupa model pembelajaran tematik integratif Penjasorkes berbasis permainan bagi siswa sekolah dasar kelas 1 Kecamatan Gantiwarno Klaten. Model disusun dalam buku petunjuk dengan judul "model permainan integratif bagi siswa sekolah dasar kelas 1". Berdasarkan penilaian para ahli, isi materi sangat baik, bahasa sangat baik, dan format penulisan sangat baik. Berdasarkan uji skala kecil dan besar secara substansi dan pelaksanaan tergolong sangat baik.
\end{abstract}

Kata Kunci: model, permainan, sekolah dasar

\section{Developing a game-based thematic integrative learning model of sports and health for elementary school students}

\begin{abstract}
The study aims at generating a game-based thematic integrative learning model of Sports and Health Education for the Grade 1 students of Elementary School in the District of Gantiwarno, Klaten. The study is a research and development initiative that consists of two stages namely preliminary study and developmental study. The preliminary study consists of literature review, review of relevant literatures and field study while the developmental study consists of planning, expert validation, small-scale testing and wide-scale testing. When the study was conducted, three experts were involved in the validation. Then, the small-scale test was administered to 16 students of Grade 1 and two teachers from the Muhammadiyah Elementary School Gantiwarno. Next, the wide-scale test was administered to two classrooms of Grade 1, which consisted of 26 students respectively, and 3 teachers from the Muhammadiyah Elementary School and the Negeri 2 Ngandong Elementary School. The result of the study is a game-based thematic integrative learning model of Sports and Health Education for the students of Grade 1 in the District of Gantiwarno Klaten. The model is designed in a manual entitled "Integrative Game Model for the Grade 1 Students of Elementary School." Based on the results of the expert judgment, the material contents are very good, the language is very good and the composition format is very good. In brief, based on the results of both the smallscale test and the wide-scale test the substance and the implementation of the model has been very good.
\end{abstract}

Keywords: models, game, elementary school 


\section{Jurnal Pendidikan Jasmani Indonesia, 13 (1), 2017 - 34}

Agung Widodo

\section{PENDAHULUAN}

Penjasorkes berperan penting dalam proses pembinaan manusia, karena penjasorkes memberikan kesempatan kepada siswa untuk terlibat langsung dalam berbagai pengalaman belajar melalui aktivitas jasmani, olahraga, dan kesehatan secara sistematis. Pelaksanaan penjasorkes di sekolah dasar, bertujuan agar siswa memiliki kemampuan sebagai berikut: (1) mengembangkan keterampilan pengelolaan diri dalam upaya pengembangan dan pemeliharaan kebugaran jasmani serta pola hidup sehat melalui berbagai aktivitas jasmani dan olahraga yang terpilih, (2) meningkatkan pertumbuhan fisik dan pengembangan psikis yang lebih baik, (3) meningkatkan kemampuan dan keterampilan gerak dasar, (4) meletakkan landasan karakter moral yang kuat melalui internalisasi nilai-nilai yang terkandung di dalam pendidikan jasmani, olahraga dan kesehatan, (5) mengembangkan sikap sportif, jujur, disiplin, bertanggungjawab, kerjasama, percaya diri dan demokratis, (6) mengembangkan keterampilan untuk menjaga keselamatan diri sendiri, orang lain dan lingkungan, dan (7) memahami konsep aktivitas jasmani dan olahraga di lingkungan yang bersih sebagai informasi untuk mencapai pertumbuhan fisik yang sempurna, pola hidup sehat dan kebugaran, terampil, serta memiliki sikap yang positif (BNSP, 2006, p.195). Berdasarkan tujuan tersebut dapat disimpulkan bahwa orientasi penjasorkes tidak semata hanya bertujuan untuk meningkatkan keterampilan motorik maupun kemampuan fisik semata melainkan juga mencakup peningkatan sikap, pengetahuan, dan keterampilan siswa.

Pembelajaran merupakan proses yang bertujuan untuk merubah perilaku peserta didik ke arah yang lebih baik. Hal ini sejalan dengan amanat UU No. 20 Tahun 2003 sebagaimana tersurat dalam penjelasan Pasal 35: kompetensi lulusan merupakan kualifikasi kemampuan lulusan yang mencakup sikap, pengetahuan, dan keterampilan sesuai dengan standar nasional yang telah disepakati. Guna mencapai tujuan pembelajaran tersebut dibutuhkan model pembelajaran.

Model pembelajaran adalah kealamiahan isi pembelajaran, strategi belajar, dan susunan interaksi sosial yang dapat menciptakan suasana belajar bagi siswa (Hopkins, 2008, p.167). Lebih lanjut, Rahyubi (2012, p.251) menyatakan "model pembelajaran adalah kerangka konseptual yang melukiskan prosedur yang sistematis dalam mengorganisasikan pengalaman belajar untuk mencapai tujuan belajar". Berdasarkan pengertian tersebut dapat disimpulkan bahwa model pembelajaran adalah pola pembelajaran yang terdiri dari suatu pendekatan, metode, strategi, dan teknik pembelajaran yang digunakan oleh guru dalam melaksanakan pembelajaran guna mencapai tujuan dari pembelajaran tersebut. Agar tujuan pembelajaran tercapai dengan optimal, dalam merancang sebuah pembelajaran harus disesuaikan dengan karakteristik siswa.

Sesuai dengan tahapan perkembangan anak, karakteristik cara anak belajar, konsep belajar dan pembelajaran bermakna, maka kegiatan pembelajaran bagi anak kelas awal sekolah dasar sebaiknya dilakukan dengan pembelajaran tematik (Pusat Kurikulum, 2006, p.5). Lebih lanjut, Webb \& Pearson (2012, p.19) menyatakan "A thematic model as one that adopts themes that are suggestive of a range of teaching ideas and often integrate several topics". Sependapat dengan pernyataan tersebut, Trianto (2011, p.147) mengemukakan bahwa pembelajaran tematik dimaknai sebagai pembelajaran yang dirancang berdasarkan tema-tema tertentu. Lebih lanjut, Suyatno (2009, p.79) menyatakan, "integratif berarti menyatukan beberapa aspek ke dalam suatu proses". Yang dimaksud tematik integratif ini mengintegrasikan sikap, keterampilan, dan pengetahuan dalam proses pembelajaran (Ahmadi \& Amri, 2014, p.51). Integratif dapat dibedakan menjadi interbidang studi dan antarbidang studi. Berdasarkan penjelasan di atas, dapat diambil kesimpulan bahwa pembelajaran tematik integratif adalah pendekatan pembelajaran yang mengintegrasikan berbagai kompetensi dari berbagai mata pelajaran ke dalam tema.

Pelaksanaan Pendidikan Jasmani, Olahraga dan Kesehatan (penjasorkes) dituntut untuk mengintegrasikan isi pembelajaran dengan mata pelajaran lain. Penjasorkes berperan penting dalam proses pembinaan manusia, karena penjasorkes memberikan kesempatan kepada siswa untuk terlibat langsung dalam berbagai pengalaman belajar melalui aktivitas jasmani, olahraga, dan kesehatan secara sistematis. 
Sebagaimana dikemukakan oleh Sukadiyanto (2013, p.2), "Penjasorkes merupakan wahana yang tepat dilakukan secara terintegratif untuk mencapai tujuan pendidikan. Dengan demikian, pembelajaran materi lain dapat diintegrasikan ke dalam pembelajaran penjasorkes, sebaliknya pembelajaran penjasorkes tidak dapat diintegrasikan ke dalam mata pelajaran yang lain".

Dalam mengembangkan model pembelajaran tematik integratif penjasorkes berbasis permainan bagi siswa SD kelas 1 ini digunakan model jaring laba-laba (webbed). Suyatno (2009, p.85) menyatakan, "webbed adalah pembelajaran terpadu yang menggunakan pendekatan tematik. Pendekatan ini pengembangannya dimulai dengan menentukan tema tertentu". Selanjutnya Fogarty (1991, p.53) mengemukakan karakteristik model jaring labalaba adalah: (1) Adanya pandangan luas secara keseluruhan dalam suatu tema yang dapat membentuk jaringan dari berbagai bidang pengembangan; (2) Menggunakan pendekatan tematik yang kemudian dapat dikembangkan lebih lanjut pada masing-masing bidang pengembangan.

Siswa sekolah dasar kelas 1 berusia antara 6-7 tahun dan masih tergolong anak usia dini. Menurut Muhammad (2009, p.99) menyatakan, pada usia anak-anak fisik sedang mengalami pertumbuhan yang baik. Pada usia ini, anak sangat senang bergerak. Aktivitas fisik sangat diperlukan untuk mengembangkan kestabilan tubuh dan kestabilan gerak serta melatih koordinasi untuk menyempurnakan berbagai keterampilan. Lebih lanjut Depdiknas (2004, p.53) menyatakan, beberapa macam gerakan yang mulai bisa dilakukan atau gerakan yang dimungkinkan bisa dilakukan anak usia sekolah dasar kelas 1 adalah gerakan-gerakan berjalan, berlari, mendaki, meloncat, berjengket, mencongklang, lompat tali, menyepak, melempar, menangkap, memantulkan bola, memukul, dan berenang.

Selanjutnya dalam penelitian dan pengembangan model pembelajaran tematik integratif penjasorkes berbasis permainan bagi siswa SD kelas 1 ini, aspek keterampilan gerak hanya difokuskan pada pengembangan keterampilan gerak melampar dan menangkap.

Berdasarkan karaktersitiknya, bermain merupakan dunia anak-anak. Menurut Semiawan (2008, p.20) bermain adalah suatu kegiatan yang serius, tetapi mengasyikkan. Lebih lanjut Wiyani (2012, p.93) menyatakan, dengan bermain anak akan memiliki kemampuan untuk memahami konsep secara ilmiah tanpa paksaan. Melalui bermain anak-anak belajar berbagai hal. Ketika bermain, anak belajar memahami orang lain dengan cara menyepakati komitmen yang dibuat dari berbagai aturan dan menilai pekerjaan secara bersama-sama. Bermain mematangkan perkembangan anak dalam semua ranah intelektual, sosial dan fisik. Permainan yang dipilih secara tepat dan terencana akan dapat mengem-bangkan fisik, kemampuan kognitif, keterampilan motorik, juga dapat mengembangkan aspek afektif dan sosial.

Berdasarkan latar belakang tersebut, secara umum tujuan penelitian ini adalah untuk mengembangkan model pembelajaran tematik integratif penjasorkes berbasis permainan bagi siswa sekolah dasar kelas 1. Secara khusus, penelitian ini dilakukan dengan tujuan untuk mengetahui: (1) langkah-langkah pembelajaran tematik integratif penjasorkes berbasis permainan bagi siswa sekolah dasar kelas 1, (2) pelaksanaan model pembelajaran tematik integratif penjasorkes berbasis permainan bagi siswa sekolah dasar kelas 1, (3) efektivitas model pembelajaran tematik integratif penjasorkes berbasis permainan bagi siswa sekolah dasar kelas 1.

Produk yang dihasilkan dalam penelitian ini adalah sebuah model pembelajaran tematik integratif penjasorkes berbasis permainan bagi siswa SD kelas 1. Model tersebut dikemas dalam sebuah buku panduan yang diberi nama "Model Permainan Integratif bagi Siswa SD Kelas 1". Buku panduan berupa penjelasan dan petunjuk pelaksanaan model pembelajaran tematik integratif penjasorkes berbasis permainan. Buku panduan memuat konsep model, tujuan, pendekatan dan metode pembelajaran, penjelasan mengenai kegiatan pelaksanaan, pedoman penggunaan dan penilaian hasil belajar model pembelajaran tematik integratif penjasorkes berbasis permainan bagi siswa SD kelas 1.

\section{METODE}

Penelitian ini merupakan penelitian pengembangan (Research and Development), karena sesuai dengan tujuan yang hendak dicapai, yaitu pengembangan model pembelajaran 
tematik integratif berbasis permainan bagi siswa SD kelas 1 yang dikemas dalam buku panduan. Produk yang dihasilkan atau divalidasi berupa buku teks mengenai proses dan prosedur pelaksanaan model pembelajaran atau metode mengorganisir pembelajaran. Hal ini sejalan dengan pendapat Borg \& Gall (1983, p.772) bahwa penelitian pengembangan adalah proses yang digunakan untuk mengembangkan dan memvalidasi produk-produk pendidikan, baik produk yang berupa objek material seperti buku teks, film pengajaran, dan sebagainya maupun produk yang berupa proses dan prosedur yang ditemukan seperti metode mengajar atau metode mengorganisir pengajaran.

Uji skala kecil dilaksanakan pada bulan Februari 2014 di SD Muhammadiyah Gantiwarno. Uji skala besar dilaksanakan pada bulan April 2014 di SD Muhammadiyah Gantiwarno dan SD Negeri 2 Ngandong, Klaten. Pada tahap validasi ahli subjek coba terdiri dari ahli penjasorkes, ahli pendidikan dasar, dan guru penjasorkes sekolah dasar (praktisi). Pada tahap uji skala kecil melibatkan 16 orang siswa dengan 2 orang guru di SD Muhammadiyah Gantiwarno, Klaten. Pada tahap uji skala besar melibatkan 2 kelas dengan 52 siswa kelas 1 dan 3 orang guru di SD Muhammadiyah Gantiwarno dan SD N 2 Ngandong, Gantiwarno.

Prosedur pengembangan penelitian ini mengadaptasi langkah penelitian pengembangan Borg \& Gall (1983, p.775), sebagai berikut: research and information collect, planing), develop pre eliminary form product, preeliminary field testing, main product revision, main field testing, operational product revision, operational field testing, final product revision, dissemination and implementation.

Berdasarkan 10 langkah penelitian dan pengembangan di atas, dalam penelitian ini pada proses pelaksanaannya melakukan adaptasi yang mengacu pada model pendekatan tersebut. Adapun adaptasi penelitian dan pengembangan ini menjadi 2 tahap yaitu: 1) tahap penelitian pendahuluan yang meliputi studi pustaka serta penelitian yang relevan dan studi lapangan, 2) tahap pengembangan yang meliputi tahap perencanaan, tahap validasi ahli, dan tahap validasi empirik (uji skala kecil dan skala besar).

Uji coba dilakukan untuk untuk mengetahui tingkat kelayakan dan tingkat efektivitas dari model pembelajaran tematik integratif penjasorkes berbasis permainan bagi siswa SD kelas 1. Uji coba produk ini dilakukan dalam uji skala kecil dan uji skala besar. Model pembelajaran yang dikembangkan dikatakan layak apabila bisa digunakan dalam pembelajaran siswa SD kelas 1 di kecamatan Gantiwarno Klaten. Model ini juga dikatakan efektif apabila dapat meningkatkan perkembangan siswa sekolah dasar kelas 1 .

Uji coba dilakukan dengan mengimplementasikan model yang dikembangkan dalam pembelajaran. Guru akan diberikan buku panduan dan diberikan penjelasan mengenai model pembelajaran yang dikembangkan untuk dilaksanakan dalam pembelajaran. Pada saat dilakukan proses implementasi model akan dilakukan observasi untuk mengetahui kelayakan model. Setelah dilakukan observasi selanjutnya dilakukan evaluasi dan revisi model.

Adapun desain uji coba menggunakan metode kuasi eksperimen dengan desain single one-shot case study. Berikut digambarkan desain uji coba:

$A=X_{1} \rightarrow O_{1} \rightarrow X_{n} \rightarrow O_{n}$

$B=X_{1} \rightarrow O_{1} \rightarrow X_{n} \rightarrow O_{n}$

Keterangan:

A \& $\mathbf{B}=$ Kelas $a$ dan kelas $b$

$\boldsymbol{X}_{1}, \boldsymbol{X}_{n}=$ Uji coba ke 1 dan ke $\mathrm{n}$

$\boldsymbol{O}_{1}, \boldsymbol{o}_{n}=$ Observasi dan Analisis ke 1 dan ke $\mathrm{n}$

Pada tahap validasi ahli subjek coba terdiri dari ahli penjasorkes, ahli pendidikan dasar, dan guru penjasorkes sekolah dasar (praktisi). Pada tahap uji skala kecil melibatkan 16 orang siswa dengan 2 orang guru di SD Muhammadiyah Gantiwarno, Klaten. Pada tahap uji skala besar melibatkan 2 kelas dengan 52 siswa kelas 1 dan 3 orang guru di SD Muhammadiyah Gantiwarno dan SD N 2 Ngandong, Gantiwarno.

Data dalam penelitian ini terdiri atas data kuantitatif dan data kualitatif. Data-data tersebut diperoleh dengan menggunakan dua macam instrumen, yaitu instrumen perlakuan 
Agung Widodo

dan instrumen pengumpul data penelitian. Data kuantitatif meliputi data tentang kemampuan sikap dan perilaku, proses keterampilan gerak, dan pengetahuan siswa selama penerapan model pembelajaran yang diperoleh dengan menggunakan instrumen penilaian masingmasing. Data tentang sikap dan perilaku, proses keterampilan gerak dan pengetahuan siswa selama penerapan model pembelajaran yang diperoleh melalui pengamatan dalam setiap pembelajaran praktik. Data kualitatif meliputi data tentang masukan-masukan dari ahli dan guru.

Pada tahap penelitian pendahuluan pengumpulan data dimaksudkan untuk memperoleh informasi mengenai pelaksanaan dan hambatan kegiatan belajar dan aktivitas jasmani dan tingkat keaktifan siswa sekolah dasar kelas 1 dalam belajar. Instrumen untuk mengetahui mengenai pelaksanaan dan hambatan pembelajaran tematik integratif berupa angket. Angket yang disusun bertujuan untuk mengungkap tentang pemahaman guru terhadap model pembelajaran tematik integratif, metode yang digunakan guru dalam mengajar, kelengkapan sarana prasarana sekolah, tingkat keaktifan siswa dalam belajar, dan penilaian hasil belajar yang dilakukan guru.

Pada tahap pengembangan, instrumen yang digunakan untuk memperoleh data dibagi ke dalam dua kelompok. Kelompok pertama instrumen yang digunakan untuk mengevaluasi model selama proses pengembangan dan ujicoba mengenai model yang dikembangkan. Instrumen yang digunakan pada kelompok pertama yaitu angket dan lembar observasi. Instrumen kelompok kedua yang digunakan untuk mengetahui tingkat pencapaian hasil belajar siswa dalam mengikuti pembelajaran. Instrumen untuk mengukur pencapai hasil belajar siswa mengunakan rubrik penilaian.

Instrumen angket ditujukan untuk ahli/praktisi dan guru partisipan. Angket untuk ahli/praktisi ditujukan untuk memperoleh penilaian/validasi dari para ahli dan praktisi terkait penyusunan draft model yang dikembangkan secara isi materi, bahasa dan format penulisan.

Lembar observasi pelaksanaan model digunakan untuk mengamati pelaksanaan pembelajaran dengan menggunakan draf model pembelajaran tematik integratif berbasis permainan bagi siswa sekolah dasar kelas 1. Lembar observasi ditujukan untuk guru pelaksana dan guru observer. Lembar observasi guru digunakan memperoleh data mengenai tingkat kelayakan dari draft model yang dikembangkan dalam kondisi sesungguhnya/lapangan.

Rubrik penilaian digunakan untuk mengukur tingkat pencapaian hasil belajar siswa dengan mengunakan model pembelajaran tematik integratif berbasis permainan bagi siswa sekolah dasar kelas 1. Rubrik penilaian disusun berdasarkan setiap indikator dalam permainan yang yang terdapat dalam model pembelajaran tematik integratif berbasis permainan bagi siswa sekolah dasar kelas 1 . Penilaian yang terdapat pada rubrik penilaian mencakup aspek sikap (mentaati peraturan), keterampilan (melempar dan menangkap bola) dan pengetahuan (membilang banyak bola dan menyebutkan).

Data yang diperoleh pada penelitian pendahuluan akan dianalisis dengan menggunakan teknik analisis deskriptif kualitatif. Analisis deskriptif kualitatif digunakan pada angket studi pendahuluan. Teknik analisis deskriptif bertujuan untuk menjelaskan karakteristik masingmasing variabel dan mempresentasikan secara obyektif terhadap data-data yang diperoleh.

Pada tahap pengembangan data yang diperoleh akan dianalisis menggunakan beberapa pendekatan yaitu: (1) Pada tahap validasi draf model, data yang diperoleh akan dideskripsikan ke dalam bentuk sajian data dan dianalisis secara kualitatif, (2) Pada uji skala kecil dan besar hasil uji coba dianalisis menggunakan pendekatan analisis deskriptif dan analisis kuantitatif (statistik). Analisis kuantitatif (statistik) menggunakan analisis statistik uji beda dengan menggunakan statistik non parametrik dengan uji Wilcoxon Signed Ranks Test.

\section{HASIL DAN PEMBAHASAN}

Berdasarkan tujuan penelitian dan pengembangan, hasil penelitian ini terdiri dari lima aspek yaitu: (1) studi pustaka, (2) studi lapangan, (3) perencanaan dan penyusunan draf awal, (4) validasi ahli, dan (5) validasi empirik yang meliputi uji skala kecil dan besar. Berikut temuan hasil dari tahapan pelaksanaan penelitian pengembangan pada Tabel 1. 
Tabel 1. Temuan Hasil Penelitian dan Pengembangan Model Pembelajaran Tematik Integratif Penjasorkes berbasis Permainan bagi Siswa SD Kelas 1

\begin{tabular}{|c|c|c|}
\hline No. & Tahapan & Hasil/Temuan \\
\hline 1. & $\begin{array}{c}\text { Penelitian } \\
\text { Pendahuluan }\end{array}$ & $\begin{array}{l}\text { a. Telah ditemukan deskripsi karakteristik siswa sekolah dasar kelas } 1 . \\
\text { b. Telah ditemukan model permainan untuk siswa sekolah dasar kelas } 1 . \\
\text { c. Telah ditemukan langkah-langkah pengembangan model pembelajaran } \\
\text { tematik integratif penjasokres berbasis permainan bagi siswa sekolah } \\
\text { dasar kelas } 1 . \\
\text { d. Siswa cukup bersemangat mengikuti pembelajaran penjasorkes } \\
\text { meskipun dengan model pembelajaran yang belum menggunakan } \\
\text { pendekatan tematik integratif. } \\
\text { e. Guru belum bisa menyusun perencanaan pembelajaran tematik } \\
\text { integratif. } \\
\text { f. Sarana dan prasarana di sekolah tidak memadai untuk melaksanakan } \\
\text { pembelajaran tematik integratif. } \\
\text { g. Dibutuhkan panduan model pembelajaran tematik integratif. }\end{array}$ \\
\hline \multirow[t]{4}{*}{2.} & Pengembangan & $\begin{array}{l}\text { Berdasarkan hasil studi pustaka dan hasil penelitian yang relevan serta } \\
\text { studi lapangan ditemukan } 3 \text { aspek model pembelajaran yang } \\
\text { dikembangkan yaitu rancangan desain pembelajaran, pelaksanann } \\
\text { pembelajaran dan penilaian hasil belajar sebagai dasar untuk menyusun } \\
\text { rancangan model pembelajaran berbasis permainan bagi siswa sekolah } \\
\text { dasar kelas } 1 \text {. Adapun hasil rancangan model pembelajaran tematik } \\
\text { integratif penjasorkes berbasis permainan bagi siswa sekolah dasar kelas } \\
1 \text { yaitu permainan Meriam Bola }\end{array}$ \\
\hline & Validasi Ahli & $\begin{array}{l}\text { Setelah dilakukan validasi oleh ahli dan dilakukan penyempurnaan maka } \\
\text { dihasilkan model pembelajaran tematik integratif penjasorkes berbasis } \\
\text { permainan bagi siswa sekolah dasar kelas } 1 \text { secara isi materi sangat baik, } \\
\text { pelaksanaan sangat baik, bahasa sangat baik dan format penulisan sangat } \\
\text { baik. }\end{array}$ \\
\hline & Ujicoba Model & $\begin{array}{l}\text { Setelah uji coba dihasilkan model pembelajaran tematik integratif berbasis } \\
\text { permainan pada skala kecil secara substansinya dan aspek pelaksanaan- } \\
\text { nya tergolong sangat baik. Pada uji skala besar substansinya dan aspek } \\
\text { pelaksanaannya tergolong sangat baik sehingga dihasilkan model yang } \\
\text { layak untuk digunakan }\end{array}$ \\
\hline & $\begin{array}{l}\text { Uji Efektivitas } \\
\text { Model }\end{array}$ & $\begin{array}{l}\text { Dihasilkan model pembelajaran tematik integratif berbasis permainan bagi } \\
\text { siswa sekolah dasar kelas } 1 \text { yang dapat meningkatkan kompetensi sikap, } \\
\text { keterampilan, dan pengetahuan siswa sekolah dasar kelas } 1 \text {. }\end{array}$ \\
\hline
\end{tabular}

\section{Studi Pustaka}

Studi pustaka dilakukan untuk mengumpulkan bahan-bahan pendukung dalam penelitian khususnya yang berkaitan dengan konsep pengembangan model pembelajaran, pendidikan siswa sekolah dasar, pembelajaran penjasorkes, dan aktivitas permainan. Tujuan dilakukan studi pustaka untuk menemukan model pembelajaran yang tepat untuk siswa siswa sekolah dasar kelas 1.

Hasil kajian studi pustaka yang berkaitan dengan konsep model pembelajaran ditemukan bahwa konsep dasar model pembelajaran yaitu: (1) Model pembelajaran meliputi pendekatan suatu model pembelajaran yang luas dan menyeluruh, (2) Model pembelajaran harus memiliki urutan-urutan atau langkah-langkah dalam melaksanakan kegiatan pembelajaran (Syntax), (3) Model pembelajaran harus memiliki aturan-aturan yang berlaku dalam proses pembelajaran dalam menciptakan interaksi dalam pembelajaran (Social system), (4) Model pembelajaran harus memiliki penjelasan perilaku yang seharusnya guru tunjukkan pada saat proses pembelajaran (Principles of reaction), (5) Model pembelajaran harus memiliki perangkat-perangkat pendukung dalam pelaksanaan proses pembelajaran (Support system), dan (6) Model pembelajaran harus memiliki pemerolehan hasil belajar yang ingin dicapai dan pemerolehan hasil belajar diluar tujuan pembelajaran (Instructional and nurturant effect). 
Agung Widodo

Hasil kajian studi pustaka yang berkaitan dengan pendidikan sekolah dasar kelas 1 ditemukan bahwa pembelajaran untuk jenjang sekolah dasar kelas 1 dilaksanakan dengan menggunakan pendekatan tematik integratif. Pembelajaran tematik integratif merupakan salah satu model pembelajaran yang digunakan dengan mempersatukan isi kurikulum secara utuh agar pembelajaran menjadi lebih bermakna. Selain itu pembelajaran didesain dalam bentuk aktivitas bermain sehingga dapat mendorong siswa untuk aktif sekaligus perkembangan kompetensi sikap, pengetahuan, dan keterampilan dapat tercapai.

\section{Studi Lapangan}

Studi lapangan dilakukan untuk mengetahui kondisi guru penjasorkes dalam merencanakan dan melaksanakan pembelajaran tematik integratif. Peneliti melakukan studi pendahuluan dengan memberikan angket kepada guru penjasorkes SD di Kecamatan Gantiwarno terkait kebutuhan model pembelajaran tematik integratif penjasorkes.

Berdasarkan data hasil analisis dari penyebaran angket untuk guru diketahui bahwa $54,5 \%$ guru belum mengetahui rencana penerapan kurikulum 2013 di SD, 90,9\% guru belum pernah mendapatkan atau mengikuti sosialisasi Kurikulum 2013, 72,7 \% guru belum mengetahui kurikulum 2013 bagi SD/MI menggunakan pendekatan tematik integratif, 72,7\% guru belum mengetahui apa itu pembelajaran tematik integratif, $81,8 \%$ guru belum bisa menyusun perencanaan pembelajaran tematik, $81,8 \%$ guru belum bisa melaksanakan pembelajaran tematik integratif, $50 \%$ siswa bersemangat mengikuti pembelajaran penjasorkes meskipun dengan model pembelajaran yang belum menggunakan pendekatan tematik integratif, 63,6\% siswa belum memiliki keberanian dalam menunjukkan keterampilan di depan kelas, $86,4 \%$ guru belum pernah mengajar penjasorkes dengan pendekatan tematik integratif, $77,3 \%$ sarana dan prasarana di sekolah tidak memadai untuk melaksanakan pembelajaran tematik integratif, $81,8 \%$ guru belum bisa membuat instrumen penilaian pembelajaran tematik integratif, $81,8 \%$ guru belum bisa menilai siswa dalam pembelajaran tematik integratif, $100 \%$ guru membutuhkan panduan model pembelajaran tematik integratif.

\section{Perencanaan dan Penyusunan Draf Awal}

Berdasarkan studi lapangan, kajian pustaka dan penelitian yang relevan dihasilkan dua aspek pembelajaran yang dikembangkan yaitu desain model pembelajaran dan implementasi model pembelajaran. Dalam pengembangan desain model pembelajaran aspek yang dikembangkan adalah konsep model, tujuan, pendekatan dan metode pembelajaran, prosedur pelaksanaan dan penilaian hasil belajar. Dalam pengembangan implementasi pembelajaran diarahkan pada pelaksanaan model pembelajaran.

Peneliti mengembangkan model pembelajaran tematik integratif penjasorkes berbasis permainan bagi siswa SD kelas 1 yang disusun dalam buku panduan "Model Permainan Integratif bagi Siswa SD Kelas 1". Dalam buku panduan tersebut terdiri dari lima permainan dilengkapi dengan langkah-langkah dan rubrik penilaian siswa.

Kelima model permainan integratif disusun berdasarkan tingkat keterampilan yang akan dikenalkan dalam model sebagai berikut:

1. Permainan Lempar-Ambil-Kembali

Mengenal karakteristik bola dan keterampilan melempar bola melampung ke arah depan.

2. Permainan Tangkap Bolaku

Mengenal karakteristik bola dan keterampilan menangkap bola yang melambung.

3. Permainan Meriam Bola 1

Mengembangkan keterampilan melempar dan menangkap bola dari jarak 1 meter, keterampilan membilang jumlah bola yang dilempar, bola yang masuk, dan bola yang tidak masuk.

4. Permainan Meriam Bola 2

Mengembangkan keterampilan melempar dan menangkap bola dari jarak 2 meter, keterampilan membilang jumlah bola yang dilempar, bola yang masuk, dan bola yang tidak masuk.

5. Permainan Meriam Bola 3 
Mengembangkan keterampilan melempar dan menangkap bola dari jarak 3 meter, keterampilan membilang jumlah bola yang dilempar, bola yang masuk, dan bola yang tidak masuk.

\section{Validasi Ahli}

Draf awal model pembelajaran tematik integrative penjasorkes berbasis permainan bagi siswa sekolah dasar kelas 1 yang telah disusun, perlu divalidasikan terlebih dahulu kepada para ahli sebelum diujicobakan di lapangan. Validasi dilakukan oleh para pakar/ahli yang terkait dengan penelitian ini. Para ahli tersebut adalah Dr. Pamuji Sukoco, M.Pd. sebagai pakar pendidikan jasmani, Dr. Muh. Nur Wangid, M.Pd. sebagai pakar pendidikan dasar, dan Muh. Wahyunto, S.Pd. sebagai praktisi/guru penjasorkes sekolah dasar. Berikut ini adalah skor hasil penilaian oleh para pakar/ahli terhadap model pembelajaran tematik-integratif penjasorkes berbasis permainan bagi siswa SD kelas 1 .

Tabel 2. Hasil Penilaian Ahli (Validator) terhadap Draf Awal Model Pembelajaran Tematik Integratif Penjasorkes Berbasis Permainan bagi Siswa Sekolah Dasar Kelas 1

\begin{tabular}{|c|c|c|c|c|c|c|c|c|c|}
\hline \multirow[t]{2}{*}{ No. } & \multirow{2}{*}{$\begin{array}{l}\text { Aspek yang } \\
\text { dinilai }\end{array}$} & \multirow[t]{2}{*}{ Indikator } & \multicolumn{3}{|c|}{$\begin{array}{l}\text { Penilaian } \\
\text { ahli }\end{array}$} & \multirow{2}{*}{$\begin{array}{c}\text { Jumlah } \\
\text { nilai }\end{array}$} & \multirow{2}{*}{$\begin{array}{l}\text { Nilai } \\
\text { rata- } \\
\text { rata }\end{array}$} & \multirow[t]{2}{*}{$\%$} & \multirow[t]{2}{*}{ Ket. } \\
\hline & & & $\overline{A 1}$ & A2 & $\mathbf{G}$ & & & & \\
\hline 1. & \multirow{4}{*}{ Isi Materi } & $\begin{array}{l}\text { Kesesuaian dengan } \\
\text { kurikulum }\end{array}$ & 1 & 1 & 1 & 3 & 3 & $100 \%$ & $\begin{array}{c}\text { Sangat } \\
\text { Baik }\end{array}$ \\
\hline 2. & & $\begin{array}{l}\text { Kesesuaian dengan } \\
\text { karakteristik siswa SD kelas } 1\end{array}$ & 1 & 1 & 1 & 3 & 3 & $100 \%$ & $\begin{array}{l}\text { Sangat } \\
\text { Baik }\end{array}$ \\
\hline 3. & & $\begin{array}{l}\text { Menarik perhatian siswa } \\
\text { untuk berpartisipasi aktif }\end{array}$ & 1 & 1 & 1 & 3 & 3 & $100 \%$ & $\begin{array}{c}\text { Sangat } \\
\text { Baik }\end{array}$ \\
\hline 4. & & $\begin{array}{l}\text { Kesesuaian dengan tujuan } \\
\text { pembelajaran }\end{array}$ & 1 & 1 & 1 & 3 & 3 & $100 \%$ & $\begin{array}{c}\text { Sangat } \\
\text { Baik }\end{array}$ \\
\hline 5. & \multirow{5}{*}{ Pelaksanaan } & $\begin{array}{l}\text { Mengembangkan aspek sikap } \\
\text { mentaati peraturan } \\
\text { Meningkatkan aspek }\end{array}$ & 1 & 1 & 1 & 3 & 3 & $100 \%$ & $\begin{array}{l}\text { Sangat } \\
\text { Baik } \\
\text { Sangat }\end{array}$ \\
\hline 6. & & $\begin{array}{l}\text { keterampilan melampar dan } \\
\text { menangkap }\end{array}$ & 1 & 1 & 1 & 3 & 3 & $100 \%$ & Baik \\
\hline 7. & & $\begin{array}{l}\text { Mengembangkan aspek } \\
\text { pengetahuan membilang } \\
\text { banyak bola dan } \\
\text { menyebutkan }\end{array}$ & 1 & 1 & 1 & 3 & 3 & $100 \%$ & $\begin{array}{c}\text { Sangat } \\
\text { Baik }\end{array}$ \\
\hline 8. & & $\begin{array}{l}\text { Aman dilakukan untuk anak } \\
\text { SD kelas } 1\end{array}$ & 1 & 1 & 1 & 3 & 3 & $100 \%$ & $\begin{array}{l}\text { Sangat } \\
\text { Baik }\end{array}$ \\
\hline 9. & & $\begin{array}{l}\text { Mudah dilaksanakan guru } \\
\text { maupun siswa }\end{array}$ & 1 & 1 & 1 & 3 & 3 & $100 \%$ & $\begin{array}{c}\text { Sangat } \\
\text { Baik }\end{array}$ \\
\hline \multirow{2}{*}{$\begin{array}{l}10 . \\
11 .\end{array}$} & \multirow{2}{*}{ Bahasa } & $\begin{array}{l}\text { Skenario pembelajaran jelas } \\
\text { dan mudah dilakukan }\end{array}$ & 1 & 1 & 1 & 3 & 3 & $100 \%$ & $\begin{array}{c}\text { Sangat } \\
\text { Baik }\end{array}$ \\
\hline & & $\begin{array}{l}\text { Petunjuk penggunaan model } \\
\text { jelas dan mudah dipahami }\end{array}$ & 1 & 1 & 1 & 3 & 3 & $100 \%$ & $\begin{array}{c}\text { Sangat } \\
\text { Baik }\end{array}$ \\
\hline \multirow{3}{*}{$\begin{array}{l}12 . \\
13 .\end{array}$} & \multirow{3}{*}{$\begin{array}{l}\text { Format } \\
\text { penulisan }\end{array}$} & $\begin{array}{l}\text { Penyajian draf model } \\
\text { pembelajaran jelas }\end{array}$ & 1 & 1 & 1 & 3 & 3 & $100 \%$ & $\begin{array}{c}\text { Sangat } \\
\text { Baik }\end{array}$ \\
\hline & & Tampilan draf model menarik & 1 & 1 & 1 & 3 & 3 & $100 \%$ & $\begin{array}{c}\text { Sangat } \\
\text { Baik }\end{array}$ \\
\hline & & Total & 13 & 13 & 13 & 39 & 39 & $100 \%$ & $\begin{array}{c}\text { Sangat } \\
\text { Baik }\end{array}$ \\
\hline
\end{tabular}

Berdasarkan penilaian dari tiga ahli (validator) terhadap draf awal model pembelajaran tematik integratif penjasorkes berbasis permainan bagi siswa SD kelas 1 ditinjau dari segi isis materi baik, pelaksanaan baik, bahasa baik, dan format penulisan baik. Penilaian menggunakan angket dengan format penilaian menggunakan skala guttman "ya" (1) dan "tidak" (0) dengan jumlah pertanyaan 13 item. Secara keseluruhan diperoleh nilai 39 dari nilai maksimum 39. Setelah dihitung presentasenya menunjukpada angka $100 \%$. Hal ini 
menunjukkan tingkat validitas model pembelajaran tematik integratif penjasorkes berbasis permainan bagi siswa SD kelas 1 tergolong dalam kategori baik. Berdasarkan pada penilaian para ahli (validator) draf awal model pembelajaran tematik integratif berbasis permainan bagi siswa sekolah dasar kelas 1 layak untuk diujicobakan.

Selain penilaian, komentar dan saran perbaikan dari para ahli (validator) juga dibutuhkan untuk perbaikan rancangan draft model pembelajaran tematik integratif penjasorkes berbasis permainan bagi siswa sekolah dasar kelas 1 kecamatan Gantiwarno Klaten yang dikembangkan. Adapun komentar dan saran dari para ahli (validator) sebagai berikut:

Tabel 3. Masukan Ahli Materi terhadap Draf Awal Model Pembelajaran Tematik Integratif Penjasorkes Berbasis Permainan bagi Siswa SD Kelas1

\begin{tabular}{ll}
\hline $\begin{array}{c}\text { Ahli } \\
\text { Materi }\end{array}$ & \multicolumn{1}{c}{$\begin{array}{c}\text { Masukan terhadap Model Pembelajaran Tematik Integratif Penjasorkes Berbasis } \\
\text { Permainan bagi Siswa Sekolah Dasar Kelas 1 }\end{array}$} \\
\hline Ahli 1 & $\begin{array}{l}\text { Instrumen dan pedoman penilaian dilengkapi sesuai dengan tujuan tiap pembelajaran. } \\
\text { Ahli } 2\end{array}$ \\
Guru & $\begin{array}{l}\text { Pengembangan indikator disesuaikan dengan KD. } \\
\text { diperjelas. }\end{array}$ \\
\hline
\end{tabular}

Keterangan: Ahli 1: Ahli Pendidikan Jasmani; Ahli 2: Ahli Pendidikan Dasar; Guru: Guru Penjasorkes Sekolah Dasar/Praktisi

Dari masukan-masukan yang diberikan oleh para ahli materi tersebut peneliti melakukan revisi terhadap draf model. Revisi yang dilakukan terhadap draf awal model pembelajaran adalah menyusun instrumen dan pedoman penilaian terhadap semua tujuan pembelajaran yang sebelumnya belum lengkap. Kemudian dilakukan pengembangan indikator yang disesuaikan dengan Kompetensi Dasar dan membuat gambar petunjuk pengaturan peralatan, ukuran dan jarak alat agar lebih jelas, dan proses pembelajaran dibagi dalam 3 tahap kegiatan dari mudah menuju sulit.

\section{Uji Skala Kecil}

Berdasarkan hasil analisis pelaksanaan model pembelajaran tematik integratif penjasorkes berbasis permainan bagi siswa sekolah dasar kelas 1 menunjukkan total nilai aspek substansi isi $13(81.25 \%)$ dan jumlah nilai aspek pelaksanaan 66 (82.5\%) maka dapat disimpulkan hasil pelaksanaan model pembelajaran tematik integratif penjasorkes berbasis permainan bagi siswa sekolah dasar kelas 1 pada uji skala kecil ditinjau dari aspek substansi isi sesuai dengan kurikulum pembelajaran dan sesuai dengan karakteristik siswa sekolah dasar kelas 1 . Selain itu juga ditinjau dari aspek pelaksanaan model pembelajaran tematik integratif penjasorkes berbasis permainan bagi siswa sekolah dasar kelas 1 pada uji skala kecil petunjuknya pelaksanaan cukup jelas, peralatannya yang digunakan sesuai, mudah, aman, menarik, bermanfaat bagi siswa dan guru.

Efektivitas model pembelajaran dilihat dari perbedaan atau selisish rata-rata skor siswa dari pertemuan 1 dan pertemuan 2. Model dikatakan efektif apabila terdapat peningkatan skor hasil belajar siswa. Hasil belajar siswa menggunakan model pembelajaran tematik integratif penjasorkes berbasis permainan bagi siswa SD kelas 1 dapat dilihat dalam Tabel 4:

Tabel 4. Data Hasil Uji Efektivitas Model Pembelajaran Tematik Integratif Penjasorkes berbasis Permainan bagi Siswa SD Kelas 1 pada Uji Skala Kecil

\begin{tabular}{cccccc}
\hline & \multicolumn{5}{c}{ Aspek } \\
\cline { 2 - 6 } Uji coba 1 dan 2 & \multicolumn{2}{c}{ Keterampilan } & \multicolumn{2}{c}{ Sikap } & \multicolumn{2}{c}{ Pengetahuan } \\
\cline { 2 - 6 } & $\mathbf{1}$ & $\mathbf{2}$ & $\mathbf{3}$ & $\mathbf{4}$ & $\mathbf{5}$ \\
\hline Mean uji coba 1 & 2.438 & 2.188 & 3.250 & 3.188 & 3.125 \\
Mean uji coba 2 & 3.000 & 2.563 & 3.500 & 3.563 & 3.625 \\
Z & -2.179 & -2.449 & -.884 & -1.732 & -2.271 \\
Asymp. Sig. (2-tailed) & .029 & .014 & .377 & .083 & .023 \\
\hline
\end{tabular}

Keterangan: 1: Keterampilan melempar; 2: Keterampilan menangkap; 3: Sikap mentaati peraturan; 4: Kemampuan membilang; 5: Kemampuan menyebutkan 
Berdasarkan hasil perhitungan pada Tabel 4, nilai signifikansi pada aspek melempar, menangkap, dan menyebutkan lebih rendah dari 0.05 atau $\rho<0.05$. Berdasarkan kriteria pengambilan keputusan yang sudah ditetapkan maka $\mathrm{H}_{0}$ ditolak. Hal ini menunjukkan bahwa terdapat perbedaan yang signifikan pada melempar, menangkap, dan menyebutkan pada pertemuan pertama dengan pertemuan kedua. Namun nilai signifikansi pada aspek mentaati dan membilang lebih tinggi dari 0.05 atau $\rho>0.05$. Berdasarkan kriteria pengambilan keputusan yang sudah ditetapkan maka $\mathrm{H}_{0}$ diterima. Hal ini menunjukkan bahwa tidak terdapat perbedaan yang signifikan pada mentaati dan membilang pada pertemuan pertama dengan kedua. Bila dilihat dari nilai rata-rata, terjadi peningkatan nilai rata-rata pada uji coba 2 pada semua aspek (melempar, menangkap, mentaati, menyebutkan, dan membilang). Berdasarkan hal tersebut dapat disimpulkan bahwa permainan meriam bola efektif untuk meningkatkan aspek sikap (mentaati), pengetahuan (menyebutkan dan membilang), dan keterampilan (melempar dan menangkap).

\section{Uji Skala Besar}

Berdasarkan hasil analisis pelaksanaan model pembelajaran tematik integratif penjasorkes berbasis permainan bagi siswa sekolah dasar kelas 1 menunjukkan total nilai aspek substansi isi 23 (95,83\%) dan jumlah nilai aspek pelaksanaan 107 (89.17\%) maka dapat disimpulkan hasil pelaksanaan model pembalajarn tematik integratif pernjasorkes berbasis permainan bagi siswa sekolah dasar kelas 1 menggunakan permainan meriam bola pada uji skala besar ditinjau dari aspek substansi isi sangat sesuai dengan kurikulum pembelajaran dan sangat sesuai dengan karakteristik siswa sekolah dasar kelas 1 . Selain itu juga ditinjau dari aspek pelaksanaan model pembelajaran tematik integratif penjasorkes berbasis permainan bagi siswa sekolah dasar kelas 1 menggunakan permainan meriam bola pada uji skala besar petunjuk pelaksanaan sangat jelas, peralatan yang digunakan sangat sesuai, sangat mudah, sangat aman, sangat menarik, sangat bermanfaat bagi siswa dan guru.

Efektivitas model pembelajaran dilihat dari perbedaan atau selisish rata-rata skor siswa dari pertemuan 1 dan 2, pertemuan 2 dan 3, dan pertemuan 1 dan 3. Model dikatakan efektif apabila terdapat peningkatan skor hasil belajar siswa. Hasil belajar siswa menggunakan model pembelajaran tematik integratif penjasorkes berbasis permainan bagi siswa SD kelas 1 dapat dilihat dalam tabel 5.

Tabel 5. Data Hasil Uji Efektivitas Model Pembelajaran Tematik Integratif Penjasorkes berbasis Permainan bagi Siswa SD Kelas 1 Uji Skala Besar Pertemuan 1 dan 2

\begin{tabular}{ccccccc}
\hline \multirow{2}{*}{ Uji coba 1 dan 2 } & \multicolumn{7}{c}{ Aspek } \\
\cline { 2 - 6 } & \multicolumn{2}{c}{ Keterampilan } & \multicolumn{2}{c}{ Sikap } & \multicolumn{2}{c}{ Pengetahuan } \\
\cline { 2 - 6 } & $\mathbf{1}$ & $\mathbf{2}$ & $\mathbf{3}$ & $\mathbf{4}$ & $\mathbf{5}$ \\
\hline Mean uji coba 1 & 2.442 & 2.346 & 3.327 & 3.135 & 3.212 \\
Mean uji coba 2 & 3.096 & 3.000 & 3.577 & 3.269 & 3.346 \\
Z & -4.333 & -4.110 & -2.343 & -1.400 & -1.698 \\
Asymp. Sig. (2-tailed) & .000 & .000 & .019 & .162 & .090 \\
\hline
\end{tabular}

Keterangan: 1: Keterampilan melempar; 2: Keterampilan menangkap; 3: Sikap mentaati peraturan; 4: Kemampuan membilang; 5: Kemampuan menyebutkan

Berdasarkan hasil perhitungan pada Tabel 5, maka nilai signifikansi pada aspek melempar, menangkap, dan mentaati lebih rendah dari 0.05 atau $\rho<0.05$. Berdasarkan kriteria pengambilan keputusan yang sudah ditetapkan maka $\mathrm{H}_{0}$ ditolak. Hal ini menunjukkan bahwa terdapat perbedaan yang signifikan pada melempar, menangkap, dan mentaati pada pertemuan pertama dengan pertemuan kedua. Namun nilai signifikasni pada aspek membilang dan menyebutkan lebih tinggi dari 0.05 atau $\rho>0.05$. Berdasarkan kriteria pengambilan keputusan yang sudah ditetapkan maka $\mathrm{H}_{0}$ diterima. Hal ini menunjukkan bahwa tidak terdapat perbedaan yang signifikan pada mentaati dan membilang pada pertemuan pertama dengan kedua. Bila dilihat dari nilai rata-rata, terjadi peningkatan nilai ratarata pada uji coba 2 pada semua aspek (melempar, menangkap, mentaati, menyebutkan, dan membilang). Berdasarkan hal tersebut dapat disimpulkan bahwa permainan meriam bola 
efektif untuk meningkatkan aspek sikap (mentaati), pengetahuan (menyebutkan dan membilang), dan keterampilan (melempar dan menangkap).

Tabel 6. Data Hasil Uji Efektivitas Model Pembelajaran Tematik Integratif Penjasorkes berbasis Permainan bagi Siswa SD Kelas 1 Uji Skala Besar Pertemuan 2 dan 3

\begin{tabular}{cccccc}
\hline \multirow{2}{*}{ Uji coba 1 dan 2 } & \multicolumn{7}{c}{ Aspek } \\
\cline { 2 - 6 } & \multicolumn{2}{c}{ Keterampilan } & \multicolumn{2}{c}{ Sikap } & \multicolumn{2}{c}{ Pengetahuan } \\
\cline { 2 - 6 } & $\mathbf{1}$ & $\mathbf{2}$ & $\mathbf{3}$ & $\mathbf{4}$ & $\mathbf{5}$ \\
\hline Mean uji coba 2 & 3.096 & 3.000 & 3.577 & 3.269 & 3.346 \\
Mean uji coba 3 & 3.308 & 3.288 & 3.635 & 3.731 & 3.750 \\
Z & -1.846 & -2.419 & -.688 & -4.235 & -4.200 \\
Asymp. Sig. (2-tailed) & .065 & .016 & .491 & .000 & .000 \\
\hline
\end{tabular}

Keterangan: 1: Keterampilan melempar; 2: Keterampilan menangkap; 3: Sikap mentaati peraturan; 4: Kemampuan membilang; 5: Kemampuan menyebutkan

Berdasarkan hasil perhitungan pada tabel 6, maka nilai signifikansi pada aspek menangkap, membilang, dan menyebutkan lebih rendah dari 0.05 atau $\rho<0.05$. Berdasarkan kriteria pengambilan keputusan yang sudah ditetapkan maka $\mathrm{H}_{0}$ ditolak. Hal ini menunjukkan bahwa terdapat perbedaan yang signifikan pada menangkap, membilang, dan menyebutkan pada pertemuan kedua dengan pertemuan ketiga. Namun nilai signifikansi pada aspek melempar dan mentaati lebih tinggi dari 0.05 atau $\rho>0.05$. Berdasarkan kriteria pengambilan keputusan yang sudah ditetapkan maka $\mathrm{H}_{0}$ diterima. Hal ini menunjukkan bahwa tidak terdapat perbedaan yang signifikan pada melempar dan mentaati pada pertemuan kedua dengan ketiga. Bila dilihat dari nilai rata-rata, terjadi peningkatan nilai rata-rata pada uji coba 3 pada semua aspek (melempar, menangkap, mentaati, menyebutkan, dan membilang). Berdasarkan hal tersebut dapat disimpulkan bahwa permainan meriam bola efektif untuk meningkatkan aspek sikap (mentaati), pengetahuan (menyebutkan dan membilang), dan keterampilan (melempar dan menangkap).

Tabel 7. Data Hasil Uji Efektivitas Model Pembelajaran Tematik Integratif Penjasorkes berbasis Permainan bagi Siswa SD Kelas 1 Uji Skala Besar Pertemuan 1 dan 3

\begin{tabular}{cccccc}
\hline \multirow{2}{*}{ Uji coba 1 dan 2 } & \multicolumn{7}{c}{ Aspek } \\
\cline { 2 - 6 } & \multicolumn{2}{c}{ Keterampilan } & \multicolumn{2}{c}{ Sikap } & \multicolumn{2}{c}{ Pengetahuan } \\
\cline { 2 - 6 } & $\mathbf{1}$ & $\mathbf{2}$ & $\mathbf{3}$ & $\mathbf{4}$ & $\mathbf{5}$ \\
\hline Mean uji coba 1 & 2.442 & 2.346 & 3.327 & 3.135 & 3.212 \\
Mean uji coba 3 & 3.308 & 3.288 & 3.635 & 3.731 & 3.750 \\
Z & -4.512 & -5.114 & -2.745 & -4.568 & -4.365 \\
Asymp. Sig. (2-tailed) & .000 & .000 & .006 & .000 & .000 \\
\hline
\end{tabular}

Keterangan: 1: Keterampilan melempar; 2: Keterampilan menangkap; 3: Sikap mentaati peraturan; 4: Kemampuan membilang; 5: Kemampuan menyebutkan

Berdasarkan hasil perhitungan pada Tabel 7, maka nilai signifikansi pada aspek melempar, menangkap, mentaati, membilang, dan menyebutkan lebih rendah dari 0.05 atau $\rho<0.05$. Berdasarkan kriteria pengambilan keputusan yang sudah ditetapkan maka $\mathrm{H}_{0}$ ditolak. Hal ini menunjukkan bahwa terdapat perbedaan yang signifikan pada melempar, menangkap, mentaati, membilang, dan menyebutkan pada pertemuan pertama dengan pertemuan ketiga. Sekain itu, dilihat dari nilai rata-rata, terjadi peningkatan nilai rata-rata pada uji coba 3 pada semua aspek (melempar, menangkap, mentaati, menyebutkan, dan membilang). Jadi dapat disimpulkan bahwa model pembelajaran tematik integratif penjasorkes dengan permainan meriam bola efektif untuk meningkatkan keterampilan melempar dan menangkap, pengetahuan membilang dan menyebutkan, serta sikap mentaati.

\section{Produk Akhir}

Produk akhir penelitian ini berupa model pembelajaran tematik integratif penjasorkes berbasis permainan bagi siswa sekolah dasar kelas 1 yang terdiri lima permainan dilengkapi dengan langkah-langkah dan rubrik penilaian siswa. Kelima model permainan integratif disusun berdasarkan tingkat keterampilan yang akan dikenalkan dalam model sebagai berikut: 
Permainan Lempar-Ambil-Kembali

Tujuan permainan ini yaitu agar siswa dapat: (1) Mentaati peraturan permainan dan instruksi guru (afektif); (2) Membilang banyak bola 1-20 (kognitif); dan (3) Melempar sejauh 3 meter (psikomotorik). Peralatan permainan antara lain: (1) Bola plastik warna-warni sejumlah siswa; dan (2) Cone sebagai pembatas. Pengaturan lapangan permainan sebagai pada Gambar 1

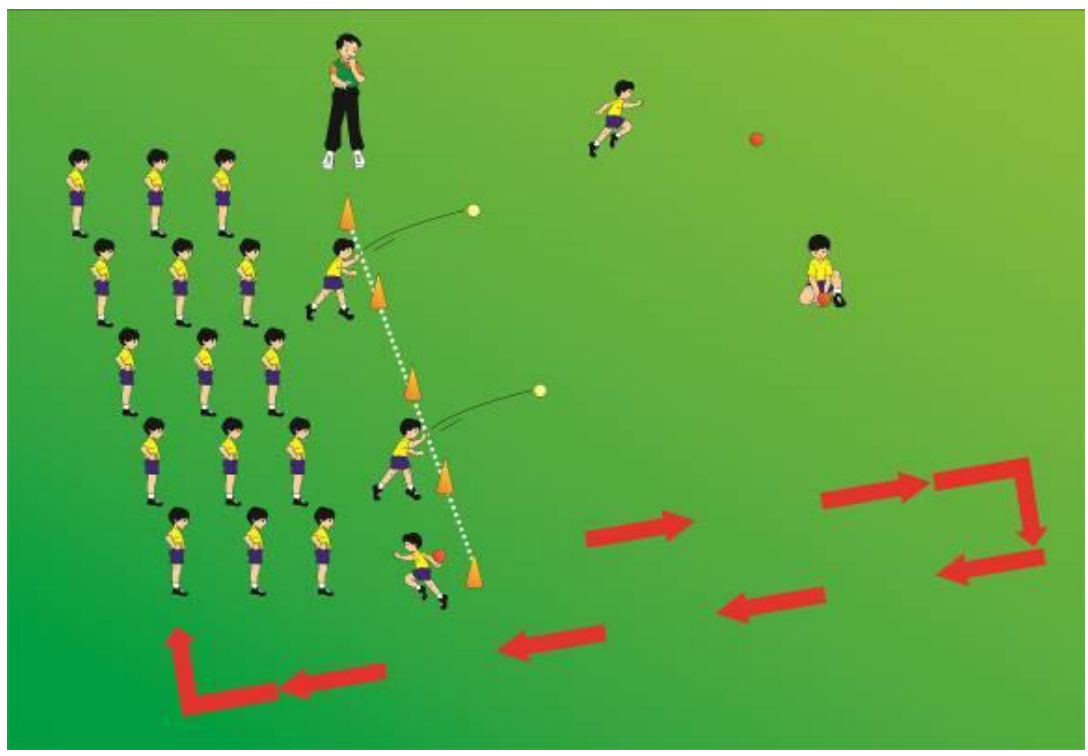

Gambar 1. Pengaturan Permainan Lempar-Ambil-Kembali.

Prosedur pelaksanaan permainan yaitu: (1) Siswa dibagi menjadi 4 baris; (2) Setiap siswa memegang 1 bola; (3) Siswa berhitung untuk menentukan urutan; (4) Siswa di baris pertama satu per satu melempar bola sejauh-jauhnya ke arah depan; (5) Saat melempar siswa mengucapkan angka sesuai dengan urutannya; (6) Setelah bola mendarat, kemudian siswa berlari mengambil bola dan kembali ke baris paling belakang; dan (7) Begitu seterusnya sampai setiap anak melakukan lemparan sebanyak 8 kali. Gambar 2 merupakan pelaksanaan permainan Lempar-Ambil-Kembali.

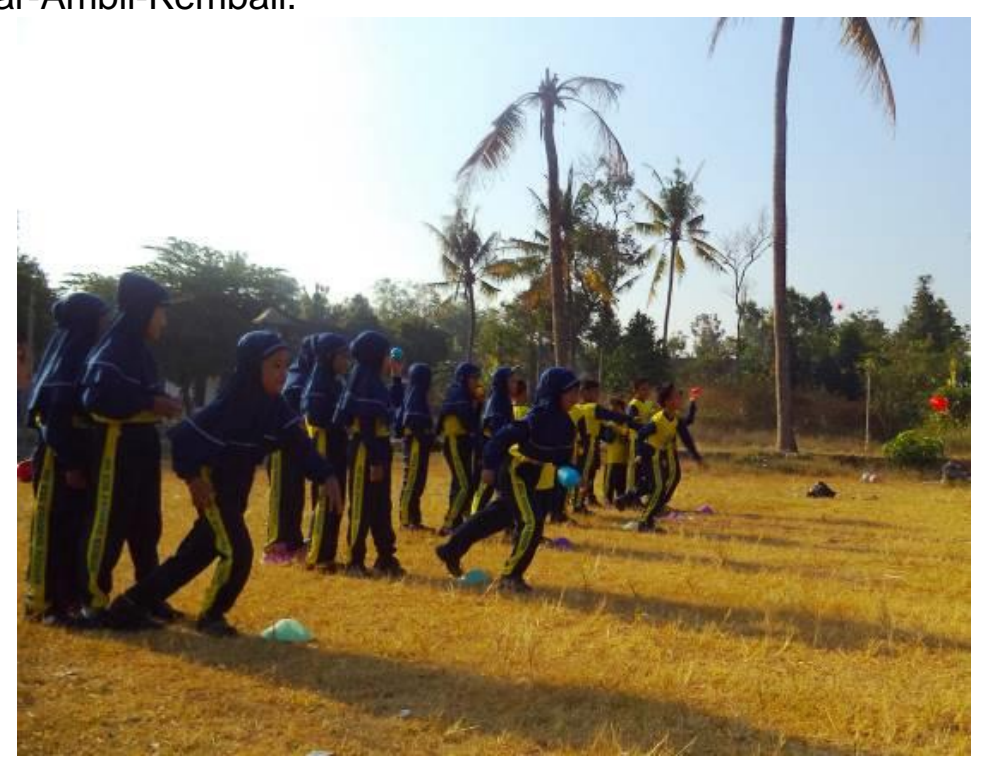

Gambar 2. Siswa Melakukan Permainan Lempar-Ambil-Kembali.

Permainan Tangkap Bolaku

Tujuan permainan ini yaitu agar siswa dapat: (1) Mentaati peraturan permainan dan instruksi guru (afektif); (2) Membilang banyak bola 1-20 (kognitif); dan (3) Melempar dan 
menangkat bola (psikomotorik). Peralatan permainan antara lain: (1) Bola plastik warna-warni sejumlah siswa; dan (2) Cone sebagai pembatas. Pengaturan lapangan permainan seperti pada Gambar 3.

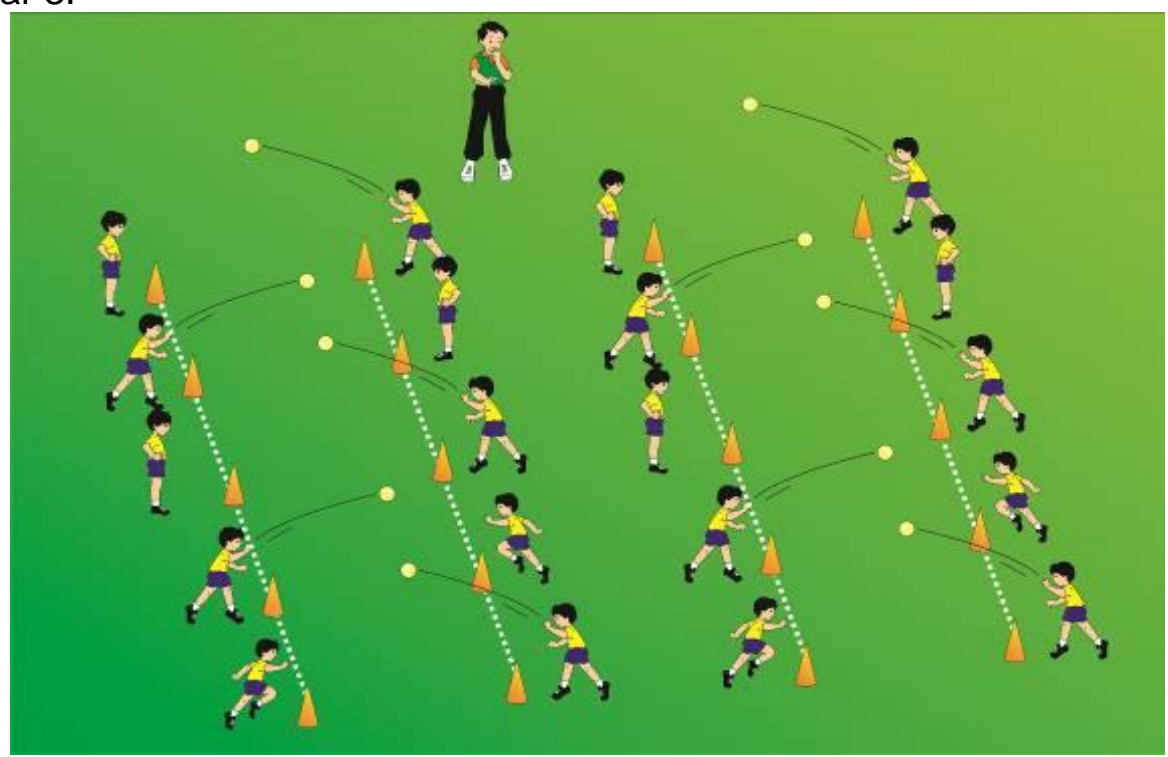

Gambar 3. Pengaturan Permainan Tangkap Bolaku.

Prosedur pelaksanaan permainan yaitu: (1) Siswa dibagi menjadi 4 baris dengan jarak antar baris sejauh 2 meter; (2) Baris 1 berhadapan dengan baris 2, baris 3 dengan baris 4 ; (3) Setiap 2 orang siswa 1 bola; (4) Siswa bermain lempar tangkap bola dengan teman yang berada di hadapannya; (5) Setiap siswa melakukan 10 lemparan dan tangkapan; dan (6) Setiap bola dipegang, anak yang memegang bola menyebutkan angka dimulai dari angka 1. Gambar 4 adalah gambar pelaksanaan permainan Tangkap Bolaku:

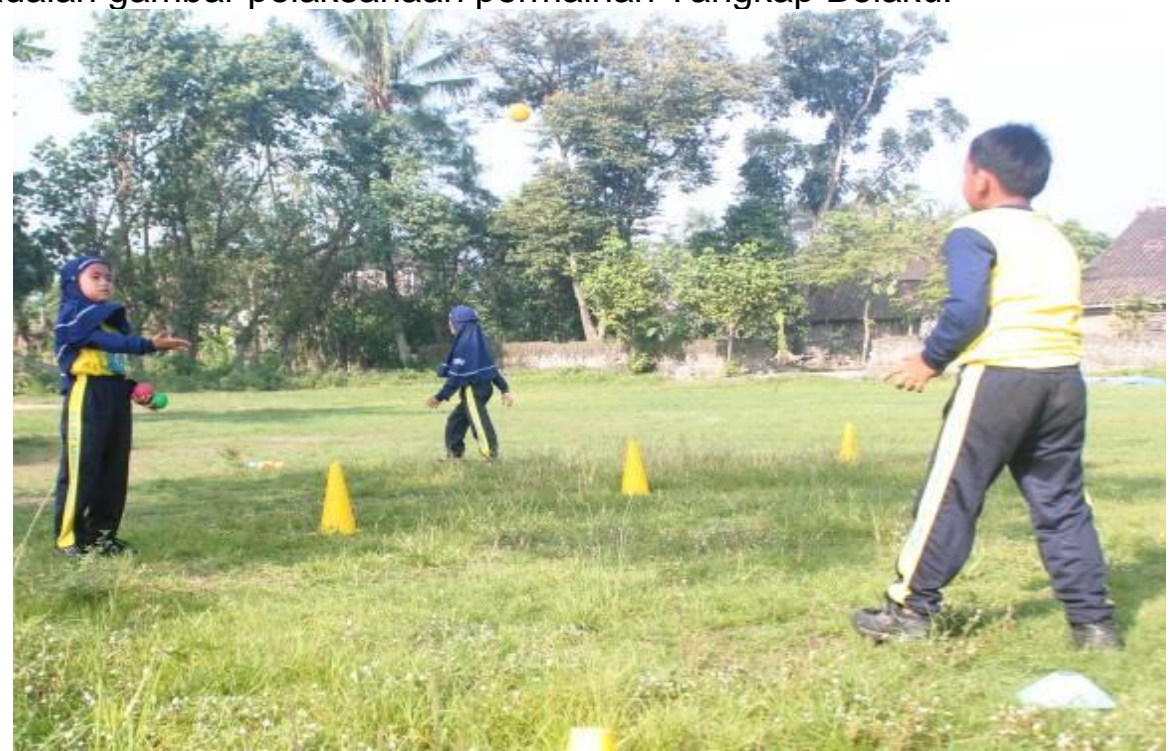

Gambar 4. Siswa Melakukan Permainan Tangkap Bolaku.

\section{Permainan Meriam Bola 1}

Tujuan permainan ini yaitu agar siswa dapat: (1) Mentaati peraturan permainan dan instruksi guru (afektif); (2) Membilang banyak bola 1-20 (kognitif); dan (3) Melempar dan menangkap bola dengan jarak 1 meter (psikomotorik). Peralatan permainan antara lain: (1) Bola plastik warna-warni; (2) Cone sebagai pembatas; (3) Ember/Kardus; dan (4) Kain Ukuran $1 \times 2$ meter. Pengaturan lapangan permainan tampak pada Gambar 5. 


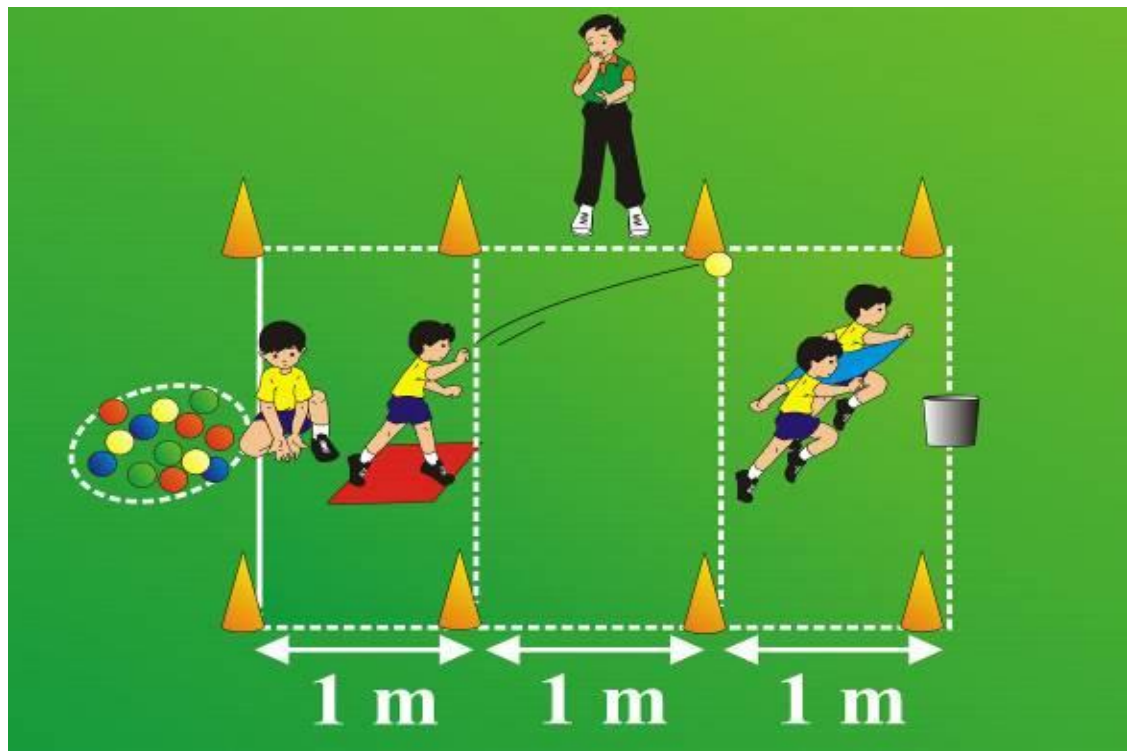

Gambar 5. Pengaturan Permainan Meriam Bola 1.

Prosedur pelaksanaan permainan yaitu: (1) Siswa dibagi menjadi beberpa kelompok, setiap kelompok terdiri dari 4 anak; (2) Setiap nggota kelompok akan menjalankan tugasnya sebagai berikut: satu anak sebagai pengisi meriam bertugas mengambil dan memberikan bola kepada anak yang bertugas sebagai meriam, satu anak sebagai meriam bertugas melemparkan bola melambung kea rah penangkap bola, dan dua anak sebagai penangkap bola bertugas menangkap bola menggunakan kain dan membawa serta memasukkan bola tersebut ke dalam ember/kardus; (3) Permainan berakhir apabila semua bola sudah dilempar; dan (4) Kelompok pemenang adalah kelompok yang memasukkan bola paling banyak. Gambar 6 adalah gambar pelaksanaan permainan Meriam Bola 1:

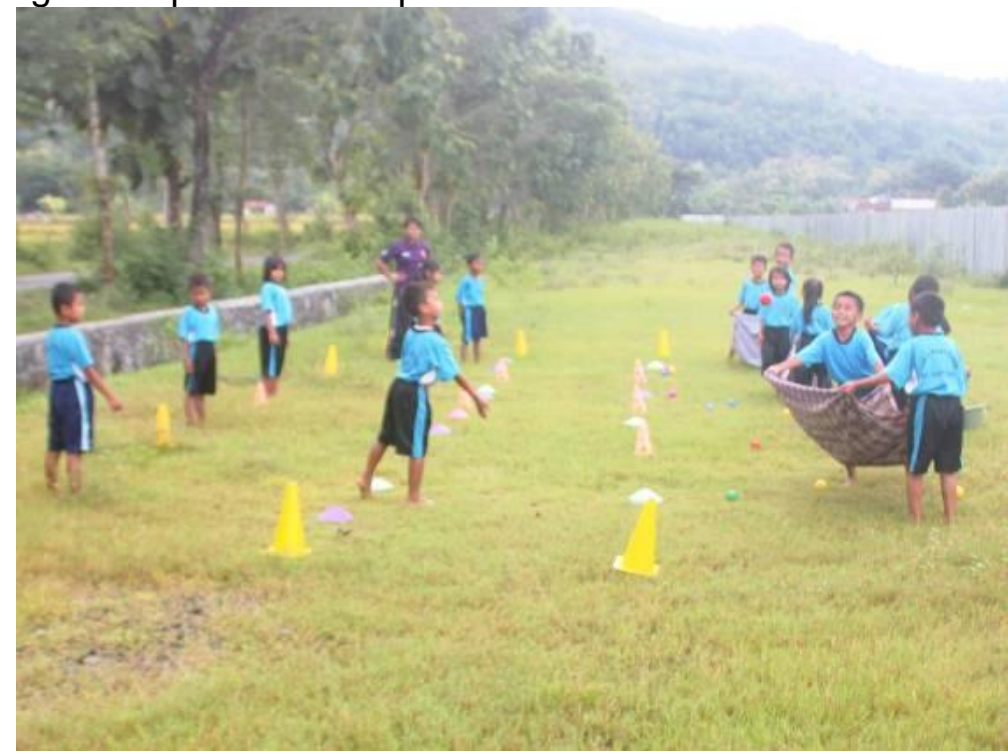

Gambar 6. Siswa Melakukan Permainan Meriam Bola 1.

\section{Permainan Meriam Bola 2}

Tujuan permainan ini yaitu agar siswa dapat: (1) Mentaati peraturan permainan dan instruksi guru (afektif); (2) Membilang banyak bola 1-20 (kognitif); dan (3) Melempar dan menangkap bola dengan jarak 2 meter (psikomotorik). Peralatan permainan antara lain: (1) Bola plastik warna-warni; (2) Cone sebagai pembatas; (3) Ember/Kardus; dan (4) Kain Ukuran $1 \times 2$ meter. Pengaturan lapangan permainan sebagai berikut: 


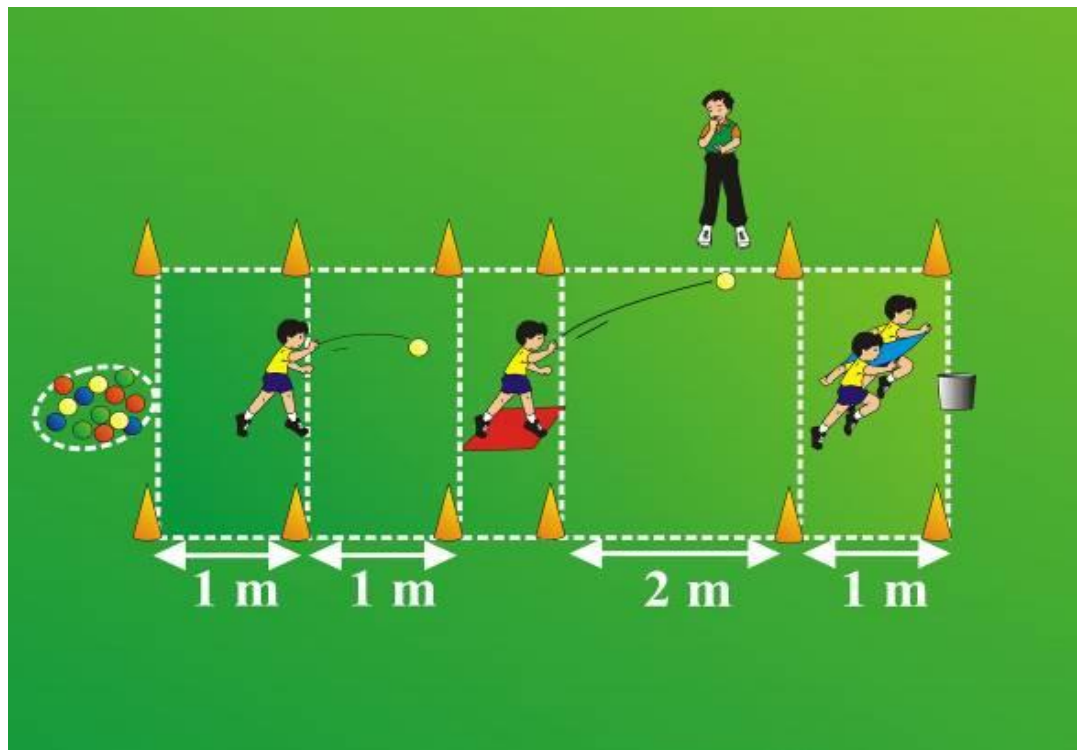

Gambar 7. Pengaturan Permainan Meriam Bola 2.

Prosedur pelaksanaan permainan yaitu: (1) Siswa dibagi menjadi beberpa kelompok, setiap kelompok terdiri dari 4 anak; (2) Setiap nggota kelompok akan menjalankan tugasnya sebagai berikut: satu anak sebagai pengisi meriam bertugas mengambil dan memberikan bola kepada anak yang bertugas sebagai meriam, satu anak sebagai meriam bertugas melemparkan bola melambung kea rah penangkap bola, dan dua anak sebagai penangkap bola bertugas menangkap bola menggunakan kain dan membawa serta memasukkan bola tersebut ke dalam ember/kardus; (3) Permainan berakhir apabila semua bola sudah dilempar; dan (4) Kelompok pemenang adalah kelompok yang memasukkan bola paling banyak. Gambar 8 adalah gambar pelaksanaan permainan Meriam Bola 2:

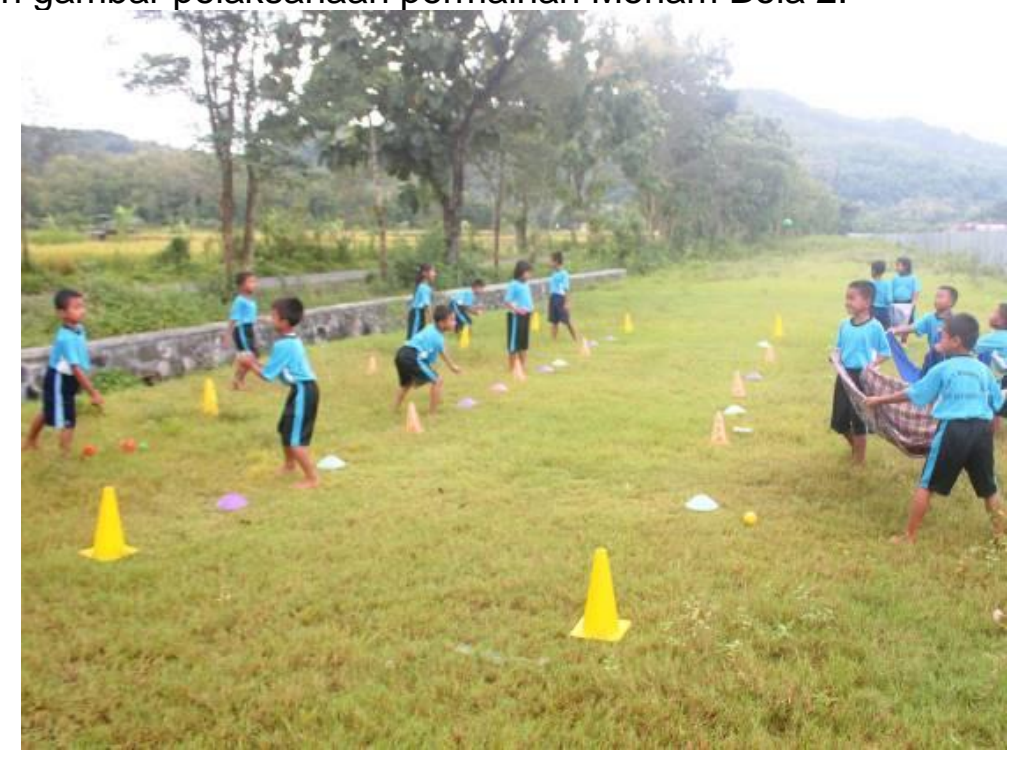

Gambar 8. Siswa Melakukan Permainan Meriam Bola 2.

\section{Permainan Meriam Bola 3}

Tujuan permainan ini yaitu agar siswa dapat: (1) Mentaati peraturan permainan dan instruksi guru (afektif); (2) Membilang banyak bola 1-20 (kognitif); dan (3) Melempar dan menangkap bola dengan jarak 3 meter (psikomotorik). Peralatan permainan antara lain: (1) Bola plastik warna-warni; (2) Cone sebagai pembatas; (3) Ember/Kardus; dan (4) Kain Ukuran $1 \times 2$ meter. Gambar 9 adalah gambar pengaturan lapangan permainan.: 


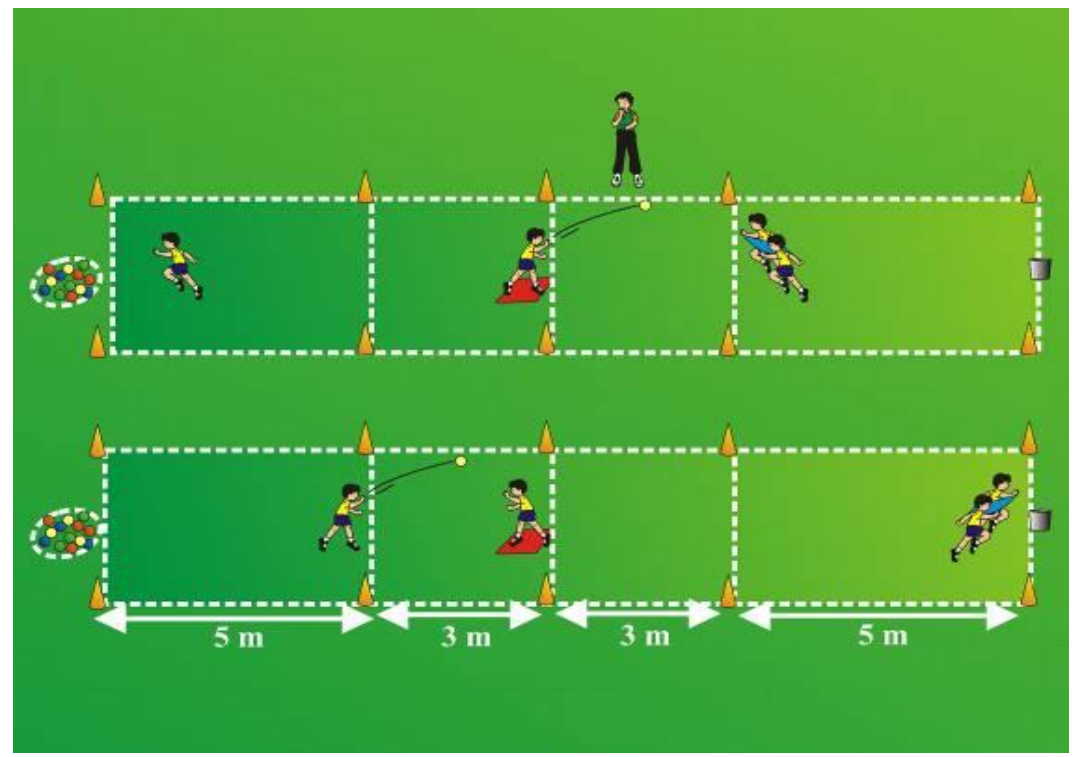

Gambar 9. Pengaturan Permainan Meriam Bola 3.

Prosedur pelaksanaan permainan yaitu: (1) Siswa dibagi menjadi beberpa kelompok, setiap kelompok terdiri dari 4 anak; (2) Setiap nggota kelompok akan menjalankan tugasnya sebagai berikut: satu anak sebagai pengisi meriam bertugas mengambil dan memberikan bola kepada anak yang bertugas sebagai meriam, satu anak sebagai meriam bertugas melemparkan bola melambung kea rah penangkap bola, dan dua anak sebagai penangkap bola bertugas menangkap bola menggunakan kain dan membawa serta memasukkan bola tersebut ke dalam ember/kardus; (3) Permainan berakhir apabila semua bola sudah dilempar; dan (4) Kelompok pemenang adalah kelompok yang memasukkan bola paling banyak. Gambar 10 adalah gambar pelaksanaan permainan Meriam Bola 3:

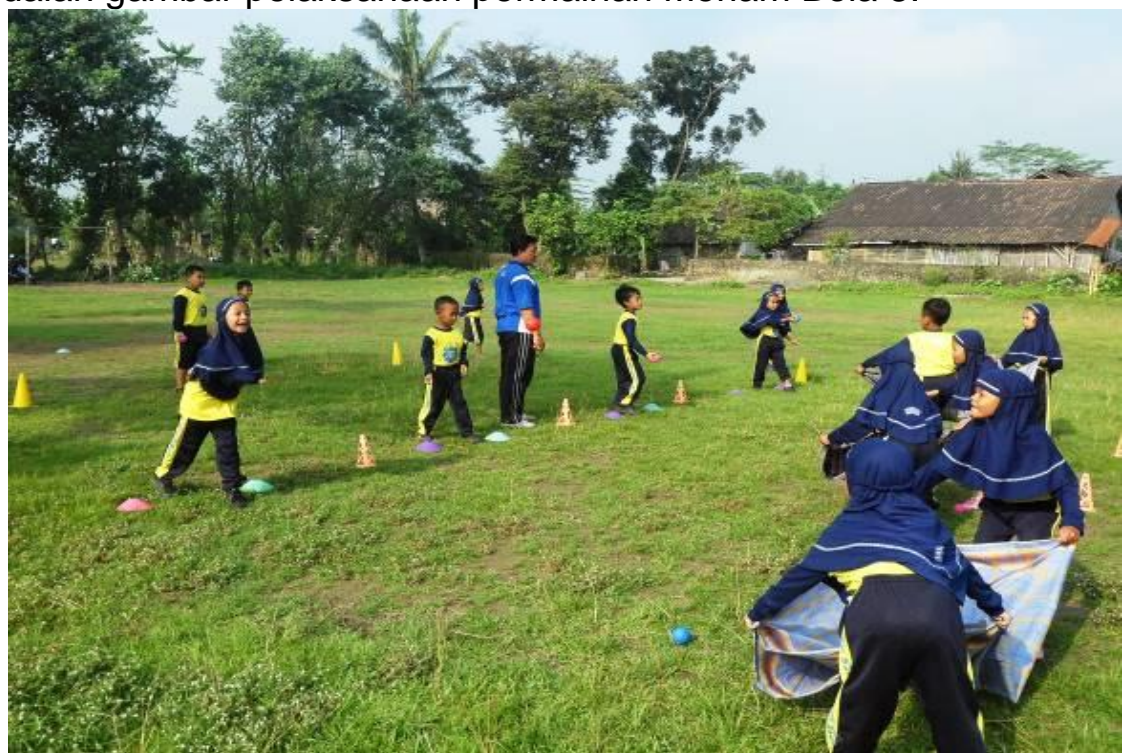

Gambar 10. Siswa Melakukan Permainan Meriam Bola 3.

\section{SIMPULAN}

Berdasarkan pada hasil penelitian dan pembahasan pada kajian produk akhir dirumuskan beberapa simpulan penelitian yang didasarkan pada rumusan masalah yaitu: Pertama, Langkah-langkah pengembangan yang digunakan dalam pengembangan model pembelajaran tematik integratif penjasorkes berbasis permainan bagi siswa sekolah dasar kelas 1 di kecamatan Gantiwarno Klaten terdiri: (1) tahap penelitian pendahuluan yang meliputi studi pustaka dan penelitian yang relevan serta studi lapangan dan (2) tahap pengembangan yang meliputi tahap perencanaan, tahap validasi ahli, dan tahap validasi emperik (uji skala 
kecil dan skala besar). Kedua, Model pembelajaran tematik integratif berbasis aktivitas jasmani untuk siswa sekolah dasar kelas 1 kecamatan Gantiwarno Klaten yang dikembangkan, berdasarkan validasi ahli dihasilkan model pembelajaran secara isi materi sangat baik, pelaksanaan sangat baik, bahasa sangat baik dan format penulisan sangat baik. Selanjutnya berdasarkan pada hasil validasi ahli tersebut, model diimplementasikan dalam uji coba melalui dua tahapan yaitu uji skala kecil dua kali dan uji skala besar tiga kali. Berdasarkan hasil pelaksanaan uji coba, substansi dan aspek pelaksanaannya tergolong sangat baik. Berdasarkan hasil validasi dan ujicoba maka model yang dikembangkan layak untuk digunakan. Ketiga, Berdasarkan perhitungan pada perbedaan pemerolehan hasil belajar pertemuan pertama dengan pertemuan ketiga menunjukkan bahwa nilai rata-rata pemerolehan hasil belajar pertemuan ketiga lebih tinggi dari nilai rata-rata pemerolehan hasil belajar pertemuan pertama. Model pembelajaran tematik integratif penjasorkes berbasis permainan efektif untuk meningkatkan kompetensi sikap (mentaati peraturan), pengetahuan (menyebutkan dan membilang banyak bola), dan keterampilan (melempar dan menangkap bola) siswa sekolah dasar kelas 1 kecamatan Gantiwarno Klaten. Efektivitas ini dapat dilihat dari perbedaan pemerolehan hasil belajar pada pertemuan pertama dengan pertemuan ketiga.

\section{DAFTAR PUSTAKA}

Ahmadi, I.K. \& Amri, S. (2014). Pengembangan \& model pembelajaran tematik integratif. Jakarta: Prestasi Pustakarya.

Borg W.R., \& Gall M.D. (1983). Education research. New York: Longman Inc.

BNSP. (2006). Standar kompetensi dan kompetensi dasar pendidikan jasmani, olahraga dan kesehatan sekolah dasar dan madrasah ibtidaiyah. Jakarta: BNSP.

Conny Semiawan. (2008). Belajar dan pembelajaran prasekolah dan sekolah dasar. Jakarta: PT. Macana Jaya Cemerlang.

Depdiknas. (2004). Perkembangan dan belajar gerak, biomekanika, dan kondisi fisik anakanak sekolah dasar. Jakarta: Depdiknas.

Fogarty, R. (1991). How to integrated the curricula. Illionis: IRI/Skylight Publishing, Inc.

Hopkins, D. (2008). A teacher's guide to classroom research. New York: Open University Press.

Muhammad, A. (2009). Menghidupkan otak kanan anak anda. Yogyakarta: Power Books.

Novan Ardy Wiyani. (2012). Konsep karakteristik dan implementasi pendidikan anak usia dini. Yogyakarta: Ar-Ruzz Media.

Pusat Kurikulum. (2006). Model pembelajaran tematik kelas awal sekolah dasar. Jakarta: Pusat Kurikulum, Badan Penelitian dan Pengembangan. Departemen Pendidikan Nasional.

Rahyubi, H. (2012). Teori-teori belajar dan aplikasi pembelajaran motorik. Majalengka: Referens.

Sukadiyanto. (September 2013). Pembelajaran penjasorkes yang terintegrasi dalam kontek pembelajaran sosial dan manajemen. Makalah disajikan dalam Seminar Nasional Olahraga, di Universitas Negeri Yogyakarta.

Suyatno. (2009). Menjelajah pembelajaran inovatif. Sidoarjo: Masmedia Buana Pustaka.

Trianto. (2011). Desain pengembangan pembelajaran tematik bagi anak usia dini TK/RA \& anak usia kelas awal SD/MI. Jakarta: Kencana Prenada Media Group.

Webb, P. \& Pearson, P. (2012). Creative unit and lesson planning through a thematic/integrated approach to TGFU. Journal of Physical Education New Zealand. 1722. 